\title{
Akdeniz Diyetine Uyum ve Üniversite Öğrencilerinin Bazı Antropometrik Özellikleri
}

\section{Adherence to the Mediterranean Diet and Some Anthropometric Measurements of University Students}

\author{
${ }^{1}$ Bircan ULAŞ KADIOĞLU, ${ }^{1}$ Şerife AYTEN \\ ${ }^{1}$ Osmaniye Korkut Ata University, Faculty of Health Sciences, Department of Nutrition and Dietetics, Osmaniye, Turkey \\ Bircan Ulas Kadioglu: http://orcid.org/0000-0002-1150-8761 \\ Şerife Ayten: http://orcid.org/0000-0001-7803-5164
}

\section{ÖZ}

Amaç: Üniversite öğrencilerinde Akdeniz Diyetine Uyum (ADU) ve AD bileşenleri ile bazı antropometrik özellikleri değerlendirmektir.

Materyal ve Metot: 510 üniversite öğrencisi ile aralık ayında yürütülen kesitsel tipte bir çalışmadır. ADU, KIDMED (Akdeniz Diyeti Kalite İndeksi) ile değerlendirilmiştir.

Bulgular: Öğrencilerin yaş medyanı 21 (2) yıldır ve çoğunluğu $(\% 60,2) \quad$ kiz öğrenciler oluşturmaktadır. 'KIDMED' puan ortalaması tüm grupta 4,0 2,6'dır. ADU, ögrencilerin \%37,3'ünde zayıf, \%53,3'ünde orta, \% 9,4'ünde yüksektir. KIDMED grubu ile yaşanılan yer, cinsiyet, yaş grubu ve bel çevresi arasında anlamlı bir farklılık bulunmamaktadır. BKİ ile KIDMED grubu arasında ise önemli bir farklılık saptanmıștır. Obez ve kilolu bireylerde günde $2 \mathrm{kez}$ den fazla meyve tüketiminin normal vücut ağırlığındaki öğrencilerden daha fazla olduğu görülmüştür. Ayrıca obez ve kilo fazlalı̆̆ kahvaltıda tahıl ürünlerini normal vücut ağırlığına sahip bireylerden daha az tükettiği saptanmıştır.

Sonuç: Bu çalışmada, ADU ile BKİ grubu arasında ilişk olduğu belirlenmiștir. Ayrıca KIDMED bileșenlerinin BKI ve cinsiyete göre farklılık gösterdiği saptanmıştır.

Anahtar Kelimeler: BKI, KIDMED, Üniversite öğrencileri

\begin{abstract}
Objective: The purpose of this research was to determine adherence in Mediterranean diet (AMD) and its components and some anthropometric measurements of university students.
\end{abstract}

Materials and Methods: This cross-sectional study was carried out on 510 university students in December, 2019. AMD was evaluated by the Mediterranean Diet Quality Index (KIDMED) questionnaire.

Results: The median age of the students was 21 (2) years and the majority of them $(60.2 \%)$ were women. The mean score on the 'KIDMED' was $4.0 \pm 2.6$ among the whole group. The AMD was poor in $37.3 \%$, medium in $53.3 \%$ and high in $9.4 \%$ of the students. There was no statistically significant differences according to KIDMED groups between gender, age groups, place of residence, waist circumference (WC), waist/hip ratio (WHR). Between BMI and KIDMED groups a significant difference was found. Overweight and Obese (OWB) students consumed fruit twice a day more frequently than normal weight (NW) students. OWB consumed less cereals or grains (bread, etc.) for breakfast than NW.

Conclusion: According to the results of this study, AMD were found to be related with BMI value. In addition, KIDMED items differ according to gender and BMI values.

Keywords: BMI, KIDMED, university students
Sorumlu Yazar / Corresponding Author:

Bircan ULAŞ KADIOĞLU

Osmaniye Korkut Ata University, Faculty of Health Sciences, 80000 , Osmaniye, Turkey

Tel: +90328 $8271010 / 4574$

E-mail: bircanulaskadioglu@osmaniye.edu.tr
Yayın Bilgisi / Article Info:

Gönderi Tarihi/ Received: 12/11/2020

Kabul Tarihi/ Accepted: 25/12/2020

Online Yayın Tarihi/ Published: 05/03/2021

Atıf / Cited: Ulaş Kadığlu B, Ayten Ş. Adherence to the Mediterranean Diet and Some Anthropometric Measurements of University Students. Online Türk Sağlık Bilimleri Dergisi 2021;6(1):121-128. doi: 10.26453/otjhs.801293 


\section{INTRODUCTION}

Being physically and mentally healthy, maintaining health in every period of life is possible with adequate and balanced nutrition. ${ }^{1}$ Healthy nutrition is take necessary nutrients the most economical way without losing nutritional value and disrupting health to growth and development, live healthy and productive for a long time. Nutrition is a sociological and psychological event as well as physiological. The conditions in some periods of life affect the eating habits.

University is very important period in terms of determining nutrition and lifestyle habits. The unhealthy lifestyle and eating habits in this period continue at a later age. ${ }^{2,3}$ Nutritional habits of university students generally change. Usually living separately from the family, new friend environment, intense university education and starting to make their own free choices often affect their eating habits negatively. ${ }^{3-5}$ Unhealthy lifestyle factors especially eating habits are one of the causes of overweight. It is known that nutrition plays a key role in the prevention of many chronic diseases such as cardiovascular diseases, many types of cancer, obesity, hypertension, diabetes, allergic diseases, osteoporosis and dental caries. Determining the nutritional habits of the students is important in terms of preventing possible disorders that may be caused by inadequate and unbalanced nutrition and regulating the nutritional habits in the adult period. ${ }^{6,7}$

There are many healthy nutrition models. However, the Mediterranean diet (MD) is accepted one of the healthiest diet models in the world. The Mediterranean Diet Quality Index (KIDMED) was developed in 2004 to evaluate compliance with MD in children, adolescents and young people. KIDMED is widely used to assess the nutritional status of children, adolescents and young people in the Mediterranean basin including Spain, ${ }^{8}$ Italy, Greece, ${ }^{9}$ Turkey $^{10}$ and Cyprus. ${ }^{11}$

The objective of this research is to examine adherence in Mediterranean diet (AMD) and the relationship between AMD and anthropometric measurements and some other sociodemographic factors in university students.

\section{MATERIALS AND METHODS}

The study approved by Osmaniye Korkut Ata University Ethics Committee (Date: 29/11/2019, decision no: 30867). This study performed with the 1964 Helsinki declaration and its later amendments or com-parable ethical standards.

This descriptive cross-sectional study was conducted with young adults aged 18-24, 510 students, 307 females and 203 males studying at Osmaniye Korkut Ata University in Osmaniye, Turkey. The data were collected in December 2019.

The sample size was calculated by using the sample size calculation formula in groups with unknown population $\mathrm{n}=\mathrm{t}^{2}(\mathrm{pq}) / \mathrm{d}^{2}(\mathrm{t}=1.96, \mathrm{~d}=0.05, \mathrm{p}=0.5)$. The number of students to be reached was determined by increasing the determined sample size by $30 \%$ (384+ $115=499)$. Students between the ages of $18-24$ who have no chronic illness and agree to participate in the study were included in the study.

A survey form which consisted of 25 questions was used. The first part of the questionnaire contains some sociodemographic questions (age, gender, place of residence). In the second part of the questionnaire, anthropometric measurements [height, body weight, upper middle arm circumference (MUAC), waist circumference (WC), hip circumference (HC)] are questioned. The body weight, height, WC, HC and MUAC measurements were taken. Height was measured using a stadiometer. Weight was measured without shoes. WC and HC were measured by the researchers using a nonstretched tape measure. WC was measured at the level of superior iliac crystals. HC was measured around the widest part of the hip.

Body mass index (BMI), waist/hip ratio (WHR) and waist/height ratio (WHtR) were calculated. BMI was calculated as weight $(\mathrm{kg}) /$ height $\left(\mathrm{m}^{2}\right)$. The participants were classified in four groups according to their BMIs: underweight (BMI $<18.5 \mathrm{~kg} / \mathrm{m} 2$ ), normal weight (18.5-24.9 kg/m2), overweight (25.0$29.9 \mathrm{~kg} / \mathrm{m} 2)$ and obese $(\geq 30.0 \mathrm{~kg} / \mathrm{m} 2) .{ }^{12}$ According to the data of WHO, abdominal obesity criterion was recommended as $\geq 102 \mathrm{~cm}$ in men and $\geq 88 \mathrm{~cm}$ in women. $\mathrm{WC} \geq 94$ and $\geq 80 \mathrm{~cm}$ for male and female, respectively was defined as overweight. ${ }^{13}$ WHtR was calculated by dividing waist circumference by height length. WHtR $>0.5$ for male and female are defined as markers of increased risk of chronic disease. WHtR $\geq 0.5$ was defined as a measure of central obesity. ${ }^{14}$

The third part of the survey comprise the KIDMED. KIDMED is a device developed in order to measure total diet quality, to assess nutrition habits in many aspects and to follow diet quality continually. The answers with a positive connotation in relation to the MD are assigned a value of +1 (12 items - 1., 2., 3., 
4., 5., 7., 8., 9., 10., 11., 13. and 15), and those with a negative connotation, a value of - 1 (4 items - 6 ., 12., 14. and 16.). The overall score can range from 4 to 12 . Total KIDMED scores were categorized 3 groups. These are $\leq 3$ reflects a poor adherence (very low diet quality), 4-7 an average adherence (improvement needed to adjust intake to MD patterns), and $\geq 8$ a good adherence to the MD (optimal diet quality). ${ }^{15,16}$

Statistical analyses: All data were evaluated using the SPSS 21.0 package program. Counts, percentage $(\%)$, and median, interquartile range values were taken to evaluate of the data. The chi-squared test was used evaluating differences between categorical variables. The significance level was taken as $\mathrm{p}<0.05$.

\section{RESULTS}

Distribution of median values of anthropometric measurements by gender are shown in Table 1 . There were 510 university students, $60.2 \%$ female $(n=307)$, enrolled in the study, with an average age of 21 years. For female and male students, median body weight was 56 and 72,5 kg, median height 162 and $178 \mathrm{~cm}$, median WC was 71 and $81 \mathrm{~cm}$, median HC was 96 and $101 \mathrm{~cm}$, median MUAC was 26 and $30 \mathrm{~cm}$, respectively. Thus, for female and male students their calculated median BMI, WHR and WHtR was 21.2 and $23.2 \mathrm{~kg} / \mathrm{m}^{2}, 0.73$ and 0.81 , and 0.43 and 0.45 respectively (Table 1 ).

$\mathrm{WC} \geq 94$ and $\geq 80 \mathrm{~cm}$ for male and female, respectively and $\geq 102$ and $\geq 88 \mathrm{~cm}$, respectively was defined as overweight and obese. ${ }^{12}$ A significant difference was found according to height, weight, BMI, WC, HC, WHR, WHtR and MUAC between male and female $(\mathrm{p}<0.001)$.

The mean score on the 'KIDMED' was 4.0 \pm 2.6 among the whole group. The adherence of Mediterranean Diet (AMD) was poor in $37.3 \%$, medium in $53.3 \%$ and high in $9.4 \%$ of the students. There was no statistically significant differences according to KIDMED groups between male and female $(p>0.05)$. Table 2 shows the distribution of gender, age and place of residence and some anthropometric measurements according to KIDMED scores.

A significant difference was found between BMI and KIDMED groups ( $\mathrm{p}=0.033$ ). According to BMI, $27.2 \%$ of overweight students and $28.6 \%$ of obese students have poor ADM. $64.2 \%$ of overweight students and $57.1 \%$ of obese student have medium ADM.

Distribution of 'yes' answers by gender and BMI values is given in Table 3 . According to KIDMED items the prevalence of "yes" answer was analyzed in gender and BMI group subcategories. Yes answer to KIDMED items 3, 6 and 10 is higher for women than men $(p<0.05)$. Yes answer to KIDMED item 5 is also higher in males than females $(p=0.070)$. overweight and obese (OWB) consumed more frequently fruit twice a day than normal weight (NW) $(p=0.020)$. OWB consumed less cereals or grains for breakfast than NW ( $\mathrm{p}=0.023)$.

\section{DISCUSSION AND CONCLUSION}

In our study, university students' AMD with the KIDMED was evaluated and its relationship with anthropometric measurements and some demographic characteristics such as age and gender were examined. The mean score on the 'KIDMED' was $4.0 \pm 2.6$ among the whole group. The AMD was poor in $37.3 \%$, medium in $53.3 \%$ and high in $9.4 \%$ of the students.

In the study by Baydemir et al., ${ }^{17}$ the KIDMED score was $3.8 \pm 1.9$ among 354 medical students in Turkey. Some specific unhealthy food choices are more widespread such as consumption of fast-food $(39.6 \%)$, 'sweets or candy several times every day (66.1\%), pasta or rice almost every day (59.0\%), commercially baked goods or pastries for breakfast $(55.1 \%) .^{17}$

In a study conducted with 193 university students in Cyprus, it was found that $26.9 \%$ had high AMD and $21.8 \%$ had poor AMD. ${ }^{18}$ Approximately $32 \%$ of the participants eating "a second portion of fruit and vegetables more than once a day", while $26 \%$ of the students consumed "more than one fast-food" and $31 \%$ consumed "sweets and sugar several times a day". ${ }^{18}$ In our study, it was found that only $10 \%$ of the students consumed fish regularly, $25.3 \%$ a second fruit and $30.3 \%$ a second vegetable a day. Another study of 726 university students conducted in Spanish showed that they moved away from the MD model by reducing their consumption of vegetables, fish, whole grains and olive oil and increasing their meat consumption. ${ }^{19}$

Healthy food selection also varies according to gender. ${ }^{19}$ In our study "Consumption of raw or cooked vegetables $>1$ times a day","Consumption of nuts regularly (at least 2-3 times per week)" and "Eating $>1$ time per week to a fast-food (hamburger) restaurant" is significantly higher in females than in males. "Regular consumption of fish (at least 2-3 times a week)" is significantly higher in males than females $(p<0.05)$. Overweight and Obese (OWB) consumed 
more frequently fruit twice a day than normal weight (NW) $(p=0.020)$. OWB consumed less cereals or grains for breakfast than NW $(p=0.023)$. Eating breakfast and consuming whole grain products for breakfast are among the healthy eating habits. Consuming fresh fruit is important in maintaining health with its vitamins and minerals, fiber and antioxidant content. However, considering the energy and sugar content, it should be consumed in the recommended amount.

In a study conducted with Italian university students, it was determined that $44 \%$ consumed an average of at least one serving of fruit a day and $22.5 \%$ consumed at least two servings of vegetables a day. Especially, $49.1 \%$ of women reached the recommended fruit consumption, while only $33.8 \%$ of men reached it. It was also found that $12.0 \%$ of men and $27.7 \%$ of women consumed at least two servings of vegetables a day. ${ }^{20}$

In our study, it was determined that compliance with the MD was associated with BMI values but no relationship WC and WHtR. In a study evaluating the AMD of 570 university students, it was stated that the frequency of low AMD among overweight students was significantly higher than those with NW $(15.5 \%$ vs $8.5 \%){ }^{21}$ Another study conducted 1717 European adolescents, Adherence to the MD did not influence the condition of over waist circumference, overfat and overweight, although certain dietary habits were identified as risk factors for their development. $^{22}$

The place of residence is one of the important factors affecting the eating habits of university students. On the other hand in our study among AMD and place of residence was no relationship. However in a study conducted in Greece, it was found that the eating habits of those living family home in the university did not change but those living alone or with friends developed unhealthy eating habits. Especially it has been determined that the consumption of fresh fruits, cooked and raw vegetables, fatty fish, seafood, pulses and olive oil decreased, and the consumption of sugar, wine, alcohol and fast food increased. $^{23}$

In conclusion, we observed poor adherence to the MD in university students. Eating at fast-food restaurants, intake of processed foods and sweets are the main unhealthy choices. Additionally, lowconsumption vegetables and fruits and fatty fish are dietary habits that bring university students closer to the Western Diet. Gender and BMI value are important in determining healthy food preferences. In this period, informing individuals about healthy nutrition is very important for healthy food choices.

Ethics Committee Approval: The study approved by Osmaniye Korkut Ata University Ethics Committee (Date: 29/11/2019, decision no: 30867).

Conflict of Interest: No conflict of interest was declared by the authors.

Author Contributions: Concept-BUK; Supervision BUK; Materials-BUK, ŞA; Data Collection and/or Processing-BUK, ŞA; Analysis and/ or Interpretation- BUK, ŞA; Writing- BUK, ŞA.

Peer-review: Externally peer-reviewed.

\section{REFERENCES}

1. Chacón-Cuberos R, Castro-Sánchez M, Muros JJ. Adherence to the Mediterranean diet is associated with physical activity, self-concept and sociodemographic factors in University student. Nutrients. 2018;10(8):966. doi:10.3390/ nu10080966

2. Arnett JJ. Adolescence and Emerging Adulthood; Pearson: Boston, MA, USA. 2014;102111.

3. Cervera F, Serrano R, Vico C, Milla M, García MJ. Food habits and nutritional assessment in a university population. Nutr. Hosp. 2013;28:438446.

4. Navarro-Gonza'lez I, Lo' pez-Nicola's R, Rodri'guez-Tadeo A, et al. Adherence to the Mediterranean diet by nursing students of Murcia (Spain). Nutricion Hospitalaria. 2014;30:165172.

5. Chacón-Cuberos R, Zurita-Ortega F, CastroSánchez M, Espejo-Garcés T, Martínez-Martínez A, Lucena-Zurita M. Descriptive analysis of the consumption of harmful substances, adherence to the Mediterranean diet and type of residence in university students of Granada. Rev. Commun. Educ. 2017;28:823-837.

6. Vivante A, Golan E, Tzur D et al. Body mass index in 1.2 million adolescents and risk for endstage renal disease. Arch Intern Med. 2012;172:1644-1650.

7. Chen Y, Copeland WK, Vedanthan R et al. Association between body mass index and cardiovascular disease mortality in East Asians and South Asians: pooled analysis of prospective data from the Asia Cohort Consortium. BMJ. 2013;347:f5446. doi:10.1136/bmj.f5446 
8. Schröder H, Mendez MA, Ribas-Barba L et al. Mediterranean diet and waist circumference in a representative national sample of young Spaniards. Int J Pediatr Obes. 2010;5:516-519.

9. Papadaki S \& Mavrikaki E. Greek adolescents and the Mediterranean diet: factors affecting quality and adherence. Nutrition. 2015;31:345349.

10. Sahingoz SA \& Sanlier N. Compliance with Mediterranean Diet Quality Index (KIDMED) and nutrition knowledge levels in adolescents. A case study from Turkey. Appetite. 2011;57:272277.

11. Lazarou C, Panagiotakos DB \& Matalas AL. Level of adherence to the Mediterranean diet among children from Cyprus: the CYKIDS study. Public Health Nutr. 2009;12:991-1000.

12. World Health Organization Global Database on Body Mass Index. https://www.euro.who.int/en/ health-topics/disease-prevention/nutrition/ahealthy-lifestyle/body-mass-index-bmi. Erişim tarihi 10 Şubat 2020

13. Report of a WHO Expert Consultation. Waist Circumference and Waist-Hip Ratio.Geneva, 2008. https://www.who.int/publications/i/ item/9789241501491. Erişim tarihi 05 Mart 2020

14.Xu Z, Qi X, Dahl A, et al. Waist to height ratio is the best indicator for undiagnosed type 2 diabetes. Diabetic Med. 2013;30:201-207.

15. Erol E, Ersoy G., Pulur A, Özdemir G, Bektaş Y. Evaluation of the Mediterranean diet quality index (KIDMED) in adolescents in Turkey. International Journal of Human Sciences [Online]. 2010;7(1):647-664.

16. Serra-Majem L, Ribas L, Ngo J, Ortega RM, Garcia A, Perez-Rodrigo C, Aranceta J. Food, youth and the Mediterranean diet in Spain. Development of KIDMED, Mediterranean diet quality index in children and adolescents. Public Health Nutrition. 2004;7:931-935.

17. Baydemir C, Ozgur EG, Balci S. Evaluation of adherence to Mediterranean diet in medical students at Kocaeli University, Turkey. The Journal of international medical research. 2018;46 (4):1585-1594.

18. Hadjimbei E, Botsaris G, Gekas V, Panayiotou AG. Adherence to the Mediterranean diet and lifestyle characteristics of university students in Cyprus: a cross-sectional survey. Journal of nutrition and metabolism. 2016:2742841. doi:10.1155/2016/2742841
19. Garcia-Meseguer MJ, Burriel FC, Garcia CV, Serrano-Urrea R. Adherence to Mediterranean diet in a Spanish university population. Appetite. 2014;78:156-164.

20. Teleman AA, de Waure C, Soffiani V, Poscia A, Di Pietro ML. Nutritional habits in Italian university students. Annali Dell'Istituto Superiore di Sanita. 2015;51(2):99-105.

21. Dura Trave T, Castroviejo GA. Adherence to a Mediterranean diet in a college population. $\mathrm{Nu}-$ tricion hospitalaria. 2011;26(3):602-608.

22. Galan-Lopez P, Sanchez-Oliver AJ, Pihu M, Gísladóttír T, Domínguez R, Ries F. Association between adherence to the Mediterranean diet and physical fitness with body composition parameters in 1717 European adolescents: The adoleshealth study. Nutrients. 2019;12(1):77. doi:10.3390/nu12010077

23.Papadaki A, Hondros G, Scott JA, Kapsokefalou M. Eating habits of university students living at, or away from home in Greece. Appetite. 2007;49 (1):169-176. 
Table 1. Distribution of median values of anthropometric measurements by gender.

\begin{tabular}{|l|c|c|c|c|}
\hline & FEMALE(n=307) & MALE (n=203) & TOTAL & p* $^{* 1}$ \\
\hline Mge & $21[2]$ & Median [IQR] & Median [IQR] & \\
\hline Weight (kg) & $56[10]$ & $20[10]$ & $21[2]$ & $<0.001$ \\
\hline Height (cm) & $162[7.5]$ & $72.5[16.7]$ & $62[18]$ & $<0.001$ \\
\hline BMI (kg/m2) & $21.2[3.5]$ & $178[9]$ & $168[15]$ & $<0.001$ \\
\hline WC (cm) & $71[8]$ & $23.2[4.2]$ & $21.9[4.4]$ & $<0.001$ \\
\hline HC (cm) & $96[8]$ & $81[11]$ & $75[12]$ & $<0.001$ \\
\hline WHR & $0.73[0.06)]$ & $0.81[0.06]$ & $0.76[0.08]$ & $<0.001$ \\
\hline WHtR & $0.43[0.05]$ & $0.45[0.06]$ & $0.44[0.06]$ & $<0.001$ \\
\hline MUAC (cm) & $26[4]$ & $30[5]$ & $27.5[5]$ & $<0.001$ \\
\hline
\end{tabular}

Mann Whitney U test; *Comparison of groups in the same line; BMI: Body Mass İndex; WC :Waist circumference $(\mathrm{cm})$; HC:Hip circumference $(\mathrm{cm})$; WHR:Waist/hip ratio; WHtR:Waist/height ratio; MUAC:Mid-upper arm circumference. 
Table 2. Distribution of gender, age and place of residence and some anthropometric measurements according to KIDMED scores.

\begin{tabular}{|c|c|c|c|c|c|c|c|c|c|}
\hline & \multicolumn{2}{|c|}{ Poor } & \multicolumn{2}{|c|}{ Medium } & \multicolumn{2}{|c|}{ Good } & \multicolumn{2}{|c|}{ Total } & \multirow[b]{2}{*}{ p } \\
\hline & $\mathbf{n}$ & $\%$ & $\mathbf{n}$ & $\%$ & n & $\%$ & n & $\%$ & \\
\hline \multicolumn{9}{|l|}{ Gender } & \multirow{4}{*}{0.831} \\
\hline Female & 116 & 37.8 & 164 & 53.4 & 27 & 8.8 & 307 & 60.2 & \\
\hline Male & 74 & 36.5 & 108 & 53.2 & 21 & 10.3 & 203 & 39.8 & \\
\hline Total & 190 & 37.3 & 272 & 53.3 & 48 & 9.4 & 510 & 100 & \\
\hline \multicolumn{9}{|l|}{ Age } & \multirow{4}{*}{0.814} \\
\hline$\leq 20$ & 98 & 38.4 & 132 & 51.8 & 25 & 9.8 & 255 & 50.0 & \\
\hline $21-22$ & 76 & 37.3 & 107 & 52.5 & 21 & 10.3 & 204 & 40.0 & \\
\hline $23-24$ & 16 & 31.4 & 33 & 64.7 & 2 & 3.9 & 51 & 10.0 & \\
\hline \multicolumn{10}{|c|}{ Place of residence } \\
\hline Family together & 26 & 33.3 & 42 & 53.8 & 10 & 12.8 & 78 & 15.3 & \multirow{4}{*}{0.379} \\
\hline Alone at home & 23 & 37.7 & 33 & 54.1 & 5 & 8.2 & 61 & 12.0 & \\
\hline Friends together & 54 & 39.1 & 72 & 52.2 & 12 & 8.7 & 138 & 27.1 & \\
\hline At dorm & 87 & 37.3 & 125 & 53.6 & 21 & 9 & 233 & 45.7 & \\
\hline \multicolumn{10}{|l|}{ BMI (kg/m2) } \\
\hline$<18.5$ & 20 & 44.4 & 23 & 51.1 & 2 & 4.4 & 45 & 8.8 & \multirow{4}{*}{$\mathbf{0 . 0 3 3}$} \\
\hline $18.50-24.99$ & 142 & 39.1 & 185 & 51 & 36 & 9.9 & 363 & 71.2 & \\
\hline $25.00-29.99$ & 22 & 27.2 & 52 & 64.2 & 7 & 8.6 & 81 & 15.9 & \\
\hline$\geq 30.00$ & 6 & 28.6 & 12 & 57.1 & 3 & 14.3 & 21 & 4.1 & \\
\hline \multicolumn{10}{|l|}{ WC (Female) } \\
\hline$<80$ & 23 & 8.4 & 144 & 52.7 & 106 & 38.8 & 273 & 88.9 & \multirow{3}{*}{0.159} \\
\hline $80-88$ & 2 & 8 & 15 & 60 & 8 & 32 & 25 & 8.2 & \\
\hline$\geq 88$ & 2 & 22.2 & 5 & 55.6 & 2 & 22.2 & 9 & 2.9 & \\
\hline \multicolumn{10}{|l|}{ WC (Male) } \\
\hline$<94$ & 67 & 37.6 & 92 & 51.7 & 19 & 10.7 & 178 & 87.7 & \multirow{3}{*}{0.505} \\
\hline $94-102$ & 5 & 31.3 & 10 & 62.5 & 1 & 6.3 & 16 & 7.9 & \\
\hline$\geq 102$ & 2 & 22.2 & 6 & 66.7 & 1 & 11.1 & 9 & 4.4 & \\
\hline \multicolumn{10}{|l|}{ WHtR } \\
\hline$<0.4$ & 20 & 33.9 & 30 & 50.8 & 9 & 15.3 & 59 & 11.6 & \multirow{3}{*}{0.476} \\
\hline$\geq 0.4-0.5$ & 144 & 38.1 & 201 & 53.2 & 33 & 8.7 & 378 & 74.1 & \\
\hline$\geq 0.5$ & 26 & 35.6 & 41 & 56.2 & 6 & 8.2 & 73 & 24.3 & \\
\hline
\end{tabular}

Pearson chi-square test; $\mathrm{p}^{*}<0.05$; BMI: Body Mass İndex; WC:Waist circumference(cm); WHtR:Waist/height ratio. 


\begin{tabular}{|c|c|c|c|c|c|c|c|c|c|c|c|c|c|c|c|c|c|c|c|}
\hline$=$ & & & 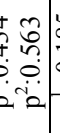 & $\begin{array}{lll}\infty & \infty \\
0 & \infty \\
0 & 0 \\
0 & \pi \\
0 & \pi\end{array}$ & & $\begin{array}{ll}\hat{a} & 0 \\
0 \\
0 & 0 \\
0 & 0 \\
0 & 0\end{array}$ & & & & & & & & & & 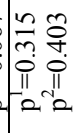 & & 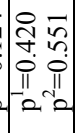 & 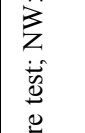 \\
\hline & $\tilde{z}$ & 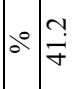 & y. & m. & $\vec{f}$ & 过 & $\stackrel{\infty}{=}$ & ì & $\begin{array}{l}t \\
\sigma^{2}\end{array}$ & $\frac{0}{\vec{n}}$ & 文 & $\begin{array}{l}\infty \\
\ddot{n} \\
\dot{n}\end{array}$ & nn & 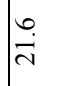 & $\begin{array}{l}\stackrel{0}{0} \\
\dot{0}\end{array}$ & $\frac{\dot{P}}{\vec{m}}$ & $\stackrel{\circ}{i}$ & $\begin{array}{l}0 \\
\dot{0}\end{array}$ & \\
\hline$\frac{\mathscr{g}}{\tilde{E}}$ & & $\Rightarrow F$ & & m & i⿱ & $\vec{m}$ & $\simeq$ & $m$ & $\vec{\infty}$ & in & $\vec{b}$ & $\vec{\sigma}$ & 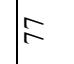 & ส & 8 & 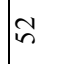 & 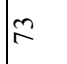 & 8 & \\
\hline$\sum_{\infty}$ & & $\therefore \mid \begin{array}{l}0 \\
0 \\
\infty\end{array}$ & : & $\overrightarrow{\mathrm{i}}$ & mis & $\underset{\substack{i \\
\text { in }}}{ }$ & $\ddot{\sigma}$ & $\stackrel{\infty}{\infty}$ & 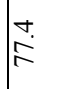 & हे & $\begin{array}{l}\stackrel{0}{R} \\
\stackrel{i}{r}\end{array}$ & 荡 & ठُ & ते & $\begin{array}{l}0 \\
\text { in }\end{array}$ & 吕 & त) & ?n & \\
\hline & & $=\left[\begin{array}{l}\infty \\
\stackrel{\infty}{-1}\end{array}\right.$ & 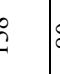 & 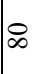 & 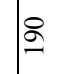 & $\dddot{Ð}$ & m & $\stackrel{\infty}{ \pm}$ & $\vec{\infty}$ & $\overline{\mathbf{\lambda}}$ & : & $\overrightarrow{\tilde{\imath}}$ & $\overrightarrow{\mathrm{N}}$ & 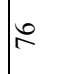 & ते & సิ & त् & 於 & \\
\hline & $\mathbb{Z}$ & ¿ & 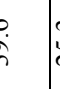 & $\hat{\varkappa}$ & $\begin{array}{l}\infty \\
\dot{m} \\
\dot{n}\end{array}$ & 迥 & 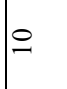 & 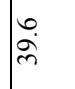 & oे & in & व.ं & 总 & $\begin{array}{l}\infty \\
\dot{\infty} \\
\dot{0}\end{array}$ & $\stackrel{+}{\vec{N}}$ & d. & $\vec{s}$ & fo & : & \\
\hline & $\stackrel{8}{*}$ & $=\underset{\sim}{ }$ & sis & సे & ఫે & $\stackrel{0}{\curvearrowleft}$ & $\vec{n}$ & तิ่ & శ్ & ᄅ्ల్ల & 总 & ते & $\sqrt{m}$ & $\stackrel{8}{ }$ & 命 & $\overrightarrow{\vec{\infty}_{i}}$ & & लm & \\
\hline & 我 & $\circ \vec{m}$ & i & 苟 & में & nై & 全 & f & $\vec{\sigma}$ & $\stackrel{n}{\tilde{y}}$ & m. & aे & 苛 & if & बे & 高 & mे & 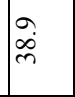 & \\
\hline & 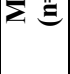 & $=\curvearrowright$ & & in & $\bar{a}$ & in & ते & $\approx$ & in & $\bar{m}$ & ले & $\cong$ & ले & g & 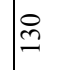 & $\cong$ & Iิ & $\bar{m}$ & \\
\hline & 为定 & $0^{\circ} \hat{\theta}$ & $\dot{b}$ & 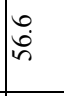 & fo & fif & $\vec{\gamma}$ & 䓟 & के & 公 & : & 离 & 苞 & in & $\overrightarrow{\text { in }}$ & $\overrightarrow{8}$ & 8 & $\overrightarrow{\dot{\theta}}$ & \\
\hline & 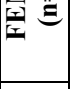 & $=\cong$ & & $\cong$ & 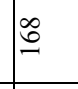 & $\overline{0}$ & तิ & $\stackrel{\partial}{0}$ & $\overbrace{\approx}$ & $\stackrel{R}{I}$ & $\frac{n}{n}$ & ڤิ & $\frac{\pi}{N}$ & 8 & $气$ & $\mid \stackrel{0}{0}$ & बे & ্ֻণী & \\
\hline & & 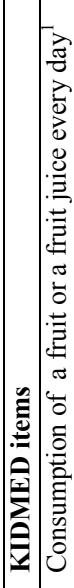 & 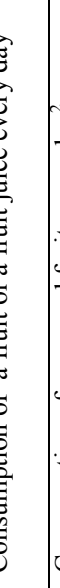 & 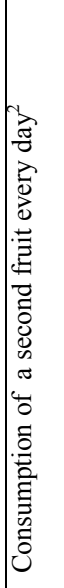 & 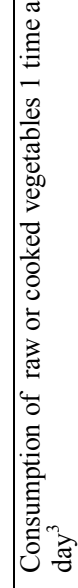 & 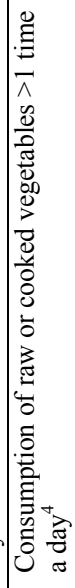 & 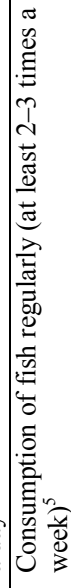 & 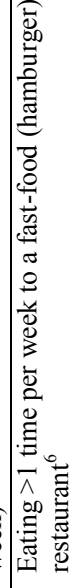 & 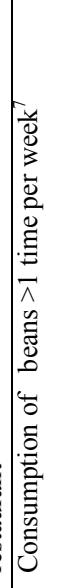 & 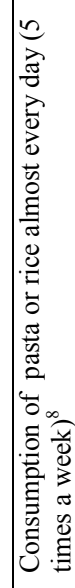 & 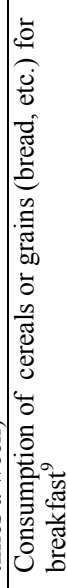 & 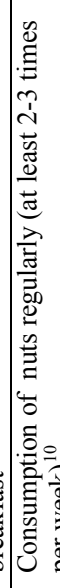 & 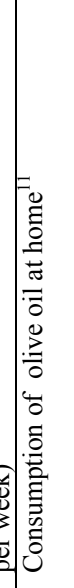 & 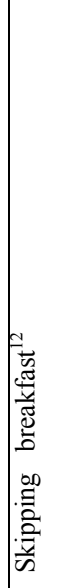 & 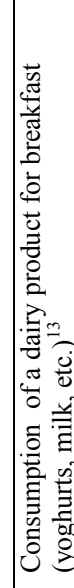 & 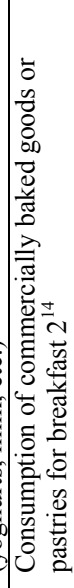 & 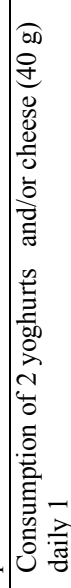 & 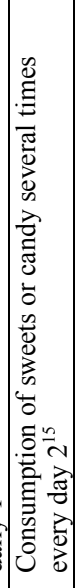 & 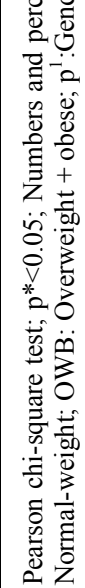 \\
\hline
\end{tabular}

